\title{
Contextual influences of health workers motivations on performance in University of Ilorin Teaching Hospital
}

\author{
Ojokuku, R. M. and Salami, A. O. \\ Department of Management and Accounting, Faculty of Management Sciences, \\ Ladoke Akintola University of Technology, Ogbomoso, Oyo State, Nigeria. \\ ABSTRACT
}

The health care sector depends to a large extent on human labour. Poor workers' motivation can greatly affect health outcomes and patient safety. This study examines the influences of motivation on the performance of health care workers using University of Ilorin Teaching Hospital as case study. 150 questionnaires were administered out which 105 were returned. 59.05\% of the workers experienced general satisfaction with their current jobs. The effect of compensation system on staff performance was determined using Tobit regression analysis and it was deduced that motivational indexes like age and management-staff relationship positively affected the performance of the workers with coefficients of $0.305,0.157$ and 0.156 respectively while years of experience and gender have negative relationships with performance with coefficients of -0.806 , 0.003 and -0.022 respectively. The result of f-ratio for Tobit regression model was 4.38 at $1 \%$ significant level which shows that motivational system positively affect performance of health care workers. It was concluded that motivation systems [monetary and non-monetary] would increase health workers performance if it is well implemented.

Keywords: Health care workers, Teaching hospital, compensation, workplace

\section{INTRODUCTION}

A number of factors ranging from the individual to national level operate together to influence how health workers take up interventions to improve their work practices(Grimshaw, et al., 2004; Rowe, et al., 2005; Shaw et al., 2005; Wallin, et al., 2006 and Woodward, 2000). Often this influence works through the local personal, education, professional, community, or institutional environment in which work takes place, or the social, cultural, economic, and political environments more generally (Rowe, et al., 2005 and Woodward, 2000). Specific efforts within these environments to manage health workers actions include a broad set of incentives and sanctions (Woodward, 2000). At the individual health worker level, many of these influences are understood to affect a worker's motivation to act in desired ways. Thus, understanding those factors that influence worker motivation is important when trying to explain why interventions that rely on changing worker behaviour succeed or fail.

However, worker motivation and its influence on changing clinical practices of health workers in lowincome settings (Dolea and Adams, 2005; Franco, et al., 2004 and Rowe, et al., 2005) is rarely explored as a major factor that may mediate or modify the effects of interventions (Dieleman, et al., 2006; Franco, et al., 2002 and 2004; and Rowe, et al., 2005). More usually, studies of health workers motivation explore determinants of motivation by examining the subjective perceptions of health workers (Agyepong, 1999; Dieleman, et al., 2003 and 2006; Kyaddondo and Whyte, 2003; Lindelow and Serneels, 2006; Manongi, et al., 2006 and Manzi, et al., 2004) either to understand effects of health sector reforms on worker performance (Agyepong, 1999; Kyaddondo and Whyte, 2003 and Lindelow and Serneels, 2006) or influences of performance management on worker motivation (Dieleman, et al., 2006; Lindelow and Serneels, 2006 and Manongi, et al., 2006).

Motivation to accept a post and to remain at that post is related to meeting needs of job security, salary and so on. An organization or institute can attract and retain personnel in their post through salaries, allowances and working conditions. When working conditions are not perceived to be satisfactory by health workers, they are likely to find ways to compensate for this. For instance, they may become more concerned with earning enough to cover their basic needs in ways other than to concentrate on their public service job. In Herzberg's theory, these are called "factors for dissatisfaction (dissatisfies)". These dissatisfies are mainly extrinsic factors (Marjolein, et al., 2003). Dissatisfies are said to be the main causes of poor job satisfaction. They 
include working conditions, salary, and relationship with colleagues, administrative supervision and so on (Dieleman, et al., 2006). The second type of motivation is to improve performance. This is linked to a feeling of self-fulfilment, achievement and recognition (Franco, et al., 2002 and World Health Organization, 1993).

However, worker motivation is not an attribute of the individual or the organization; rather, it results from an interaction between the worker and the work environment. Hence policy and social environment can affect it (Franco, et al., 2004). The health care sector is important, and the quality and efficiency of service depend to a large extent on human labour. Poor worker motivation can greatly affect health outcomes and patient safety. Poor worker motivation is common and can manifest as lack of courtesy to patients; tardiness and absenteeism; poor process quality, such as failure to conduct proper patient examinations; and failure to treat patients in a timely manner (Gilson, et al., 1994). In the workforce, it can manifest in high staff turnover rates, high vacancy rates and indifferent performance (Bennett and Lynne, 1999).

It is important to know the factors that affect workers motivation amongst the health care workers. These issues are important. A worker may be competent, but what makes the individual come to work regularly, work diligently and be willing to carry out necessary tasks and be flexible is his/her level of motivation (Bennett and Lynne, 1999). Since the beginning of the economic crisis in the 1980s, the health sector has suffered dramatically, as has all other public services activities in Nigeria. The decline in the health sector is evidenced by worsening of the health indices. This has resulted in an exodus of health professionals to the extent that Nigeria, one of the major exporters of health personnel in Africa (Stilwell, 2004). Knowledge of the influences of health workers motivation on their performance can be exploited by managers to improve health sector performance in general. This study thus examines the influences of motivation on the performance of health care workers using University of Ilorin Teaching Hospital as a case study.

\section{MATERIALS AND METHODS}

Study Design: The study was a cross-sectional study of University of Ilorin Teaching Hospital owned health facilities located in the north central region in Nigeria.
Study Population: At present, year 2010, there are twenty (20) teaching hospitals in Nigeria located in Abia [Abia state]; Zaria [Kaduna state]; Kano [Kano state]; Abakaliki [Ebonyi state]; Jos [Plateau state], Ikeja [Lagos state]; Idi Araba [Lagos state]; Nnewi [Anambra state]; Ile-Ife [Osun state], Sagamu [Ogun state], Irrua [Edo state], Benin city [Edo state], Calabar [Cross river state], Ibadan [Oyo state], Ilorin [Kwara state], Maiduguri [Borno state], Enugu [ Enugu state], Port Harcourt [River state], Sokoto [Sokoto state] and Osogbo [Osun state]. All the aforementioned hospitals are using similar mode of operations. Headed by the chief medical director and all administrative matters are being controlled by director of administration. Hence, the study population comprised of health care workers in the selected hospital totalling one hundred and fifty [150].

Sampling Method and Size: Out of the one hundred and fifty (150) health workers in the University of llorin Teaching as at the time of this study, the sampling size for the study was made up of staff by their job descriptions which include: Doctors, Nurses, Pharmacists, Laboratory scientists and other supporting staff (hospital assistants, health attendants, securities, cleaners, consultants, x-ray technologists and consultants]. A sample of one hundred and five [105] health workers were selected using simple random sampling technique. This was also based on the basis of the respondents that answered and returned the questionnaires correctly.

Methods of Data collection: The selected hospital was visited on weekdays between 9 and 10 am over a period of 3 weeks. The purpose of the study was explained to the management of the hospital and permission was obtained. All departments (both clinical and supporting services] in the hospital were included in the study. Table 1 shows the list of health workers recruited into the study.

In each department, a list of all workers scheduled to be on duty at the time of the assessment was made using that list, the entire staff at work during the period of the visit was identified, and informed consent was obtained. A self-administered semistructured questionnaire was given to all health care workers identified. The questionnaires explored the effect of monetary factors, societal expectations; inter personal relationships, quality of supervision and managerial characteristics on the health workers' job satisfaction. 
Table 1: Distribution of healthcare workers recruited in the study

\begin{tabular}{|l|l|l|}
\hline Job descriptions & Frequency & Percentage (\%) \\
\hline Doctors & 6 & 5 \\
\hline Nurses / midwives & 33 & 31.4 \\
\hline Pharmacists & 5 & 4.8 \\
\hline Hospital assistants & 23 & 21.9 \\
\hline Health attendants & 10 & 9.5 \\
\hline Securities & 4 & 3.8 \\
\hline Laboratory scientists & 4 & 3.8 \\
\hline Cleaners & 11 & 10.5 \\
\hline Consultants & 6 & 5.7 \\
\hline X-ray Technologists & 3 & 2.9 \\
\hline Total & 105 & 100 \\
\hline
\end{tabular}

Source: Field survey, 2010

Study Hypothesis: The following hypothesis was tested in the course of the study:

Ho: The motivational systems of University of llorin Teaching Hospital have no significant influence on the performance of the health care workers.

Methods of Data Analysis: Percentages were used to depict data on socio-economic characteristics of the respondents such as gender, age, years of experience and job descriptions. While hypothesis was tested using Tobit regression model as indicated in SPSS 10 statistical packages.

\section{RESULTS AND DISCUSSION RESULTS}

Socio-economic characteristics of the respondents: A total of 150 questionnaires were distributed of which 105 were returned, the response rate was $70 \%$. Thirty-one $(29.5 \%)$ of the respondents were females and seventy four (70.5\%) were males (Table 2). Also table 2 depicts that majority of the respondents fall between age groups 31-50 years [86(81.9\%)] with a sizeable proportion below $30[6(5.7 \%)]$ and above 50[13(12.4\%)]. Thirty-three $(31.4 \%)$ of the respondents were nurses/ midwives, six $(5 \%)$ of the respondents were doctors, five $(4.8 \%)$ were pharmacists, 23(21.9\%) were hospital assistants, 10(9.5\%) were hospital attendants, $4(3.8 \%)$ of the respondents were security officers, $4(3.8 \%)$ of the respondents were laboratory scientists, $11(10.5 \%)$ of the respondents were cleaners, $6(5.7 \%)$ and $3(2.9 \%)$ were consultants and $X$-ray technologists that were recruited in the study respectively. In the same vein, $49(46.7 \%)$ of the respondents has been on the present job for 1-4 year[s], $40(38.1 \%)$ of the respondents has spent between 5-10 years on their present job while
$16(15.2 \%)$ of the respondents has been on their present job for over 10 years (Table 2)

Workload and remuneration: The average number of hours worked per week by nurses / midwives was 46.40 hours [maximum 80 hours and minimum 29 hours]. Laboratory scientists 50.70 hours on the average [maximum 84 hours and minimum 30 hours], also average number of hours worked by Pharmacists was 62 hours [maximum 80 hours and minimum 40 hours]. Also, for Doctors, average number of hours work was 52.70 hours [ maximum 89 hours and minimum 25 hours] and for other supporting staff 50.1 hours on the average [maximum 84 hours and minimum 30 hours]. (Table 3 )

The average income of nurses/ midwives was US $\$ 312.76$ [maximum US $\$ 466.66$ and minimum $\$ 75.00]$; Laboratory scientists, US $\$ 321.76$ [maximum, US $\$ 478.00$ and minimum $\$ 66.66$ ]; Pharmacists, US \$354.83 [maximum, US \$354.83 and minimum US \$354.83]; Doctors, US \$639.64 [maximum, US $\$ 900.00$ and minimum, US \$441.66] and for other supporting staff US, \$155.66 [maximum, US $\$ 483.33$ and minimum US \$56.66]. (Table 3)

Also, table 4 shows that $62(59.05 \%)$ of the respondents were happy with their workload, whereas 36 (34.3\%) felt overworked and 7 (6.65\%) were indifference. Majority of the health personnel who felt overworked were nurses [13] and other supporting staff [20]. In the same vein, 68 (64.76\%) of the respondents reported that they were paid regularly as and when due. $50(47.62 \%)$ of the respondents were not satisfied with their present salaries, of these, nurses/midwives [22] and other supporting staff [20] constituted the greatest proportions. (Table 4) 
Am. J. Sci. Ind. Res., 2011, 2(2): 216-223

Table 2: Age, sex and number of years on the present job

\begin{tabular}{|c|c|c|c|c|c|c|}
\hline Variables & $\begin{array}{l}\text { Nurses } \\
n=33\end{array}$ & $\begin{array}{l}\text { Laboratory } \\
\text { Scientists } \\
n=4\end{array}$ & $\begin{array}{l}\text { Pharmacists } n \\
=5\end{array}$ & $\begin{array}{l}\text { Doctors } n \\
=6\end{array}$ & $\begin{array}{l}\text { Other } \\
\text { supporting } \\
\text { staff } \\
n=57\end{array}$ & $\begin{array}{l}\text { Total } \\
\mathrm{N}=105\end{array}$ \\
\hline $\begin{array}{l}\text { SEX } \\
\text { Female } \\
\text { Male }\end{array}$ & $\begin{array}{l}20 \\
13\end{array}$ & $\begin{array}{l}1 \\
3\end{array}$ & $\begin{array}{l}1 \\
4\end{array}$ & $\begin{array}{l}3 \\
3\end{array}$ & $\begin{array}{l}6 \\
51\end{array}$ & $\begin{array}{l}31(29.5 \%) \\
74(70.5 \%)\end{array}$ \\
\hline $\begin{array}{l}\text { AGE [years] } \\
20-30 \\
31-40 \\
41-50 \\
51-\text { Above }\end{array}$ & $\begin{array}{l}3 \\
20 \\
10 \\
0 \\
\end{array}$ & $\begin{array}{l}0 \\
3 \\
1 \\
0 \\
\end{array}$ & $\begin{array}{l}0 \\
5 \\
0 \\
0\end{array}$ & $\begin{array}{l}1 \\
4 \\
1 \\
0\end{array}$ & $\begin{array}{l}2 \\
6 \\
36 \\
13 \\
\end{array}$ & $\begin{array}{l}6(5.7 \%) \\
38(36.2 \%) \\
48(45.7 \%) \\
13(12.4 \%)\end{array}$ \\
\hline $\begin{array}{l}\text { Number of } \\
\text { years on } \\
\text { present job } \\
0-4 \\
5-10 \\
\text { Above } 10\end{array}$ & $\begin{array}{l}13 \\
18 \\
2\end{array}$ & $\begin{array}{l}1 \\
3 \\
0\end{array}$ & $\begin{array}{l}1 \\
4 \\
0\end{array}$ & $\begin{array}{l}1 \\
4 \\
1\end{array}$ & $\begin{array}{l}33 \\
11 \\
13\end{array}$ & $\begin{array}{l}49(46.7 \%) \\
40(38.1 \%) \\
16(15.2 \%)\end{array}$ \\
\hline
\end{tabular}

Source: Field survey, 2010

Table 3: Distribution of number of working hours per week and income amongst the study population

\begin{tabular}{|c|c|c|c|c|c|}
\hline Variables & $\begin{array}{l}\text { Nurse/midwives } \\
\mathrm{n}=33\end{array}$ & $\begin{array}{l}\text { Laboratory } \\
\text { Scientists } \\
n=4\end{array}$ & $\begin{array}{l}\text { Pharmacists } \\
n=5\end{array}$ & $\begin{array}{l}\text { Doctors } \\
n=6\end{array}$ & $\begin{array}{l}\text { Other supporting } \\
\text { staff } \\
n=57\end{array}$ \\
\hline $\begin{array}{l}\text { Hours / weeks: } \\
\text { Mean } \\
\text { Maximum } \\
\text { Minimum }\end{array}$ & $\begin{array}{l}46.40 \\
80 \\
29\end{array}$ & $\begin{array}{l}50.72 \\
84 \\
30\end{array}$ & $\begin{array}{l}62 \\
80 \\
40\end{array}$ & $\begin{array}{l}52.70 \\
89 \\
25\end{array}$ & $\begin{array}{l}50.1 \\
84 \\
30\end{array}$ \\
\hline $\begin{array}{l}\text { Income / Month } \\
\text { US \$: } \\
\text { Mean } \\
\text { Maximum } \\
\text { Minimum }\end{array}$ & $\begin{array}{l}312.76 \\
466.66 \\
75.00\end{array}$ & $\begin{array}{l}321.76 \\
478.00 \\
66.00\end{array}$ & $\begin{array}{l}354.83 \\
354.83 \\
354.83\end{array}$ & $\begin{array}{l}639.64 \\
900.00 \\
441.66\end{array}$ & $\begin{array}{l}155.66 \\
483.33 \\
155.66\end{array}$ \\
\hline
\end{tabular}

Source: Field survey, 2010

Managerial characteristics: $32(30.5 \%)$ of the health workers felt management of their hospital was very open. $42(40 \%)$ felt the management was open. $23(21.9 \%)$ felt the management was guarded. 87 $(82.86 \%)$ of the health workers felt the management of their hospital was supportive of staff welfare; 77 (73.31\%) felt the management of the hospital was supportive of staff training and development and 79 (75.24\%) of the respondents felt they could express themselves without fear of retribution.

Managerial characteristics that motivated health workers were of good interpersonal relationships [31 $(29.53 \%)]$, good welfare package for staff [22 (20.95\%)], career development [7(6.67\%)], freedom of expression [13(12.38\%)]; while $20(19.05 \%)$ of the workers did not respond to the question (Table 5). Only two workers $(1.9 \%)$ in the other supporting staff category felt that there was availability of material to work with fairness (Table 5)

Factors militating against compensation system and solutions to curb such factors: Majority of the respondents agreed that political interference $[\mathrm{PI}$ $(96.2 \%)]$, budget shortfalls [ABS (98.1\%)], lack of good governance [LG (100\%)] and inadequate improvement of the human resources [IHR (100\%)] were the factors militating against the effectiveness of compensation system in University of llorin, Teaching Hospital. (Table 6). The study also revealed that radical change in management culture [RCMC $(100 \%)]$, adequate budget supply [PGB (90.5\%)], provision of good governance [PGG (100\%)] and improvement of human resources situation [HR (99\%)] can help to curb the factors militating against effective compensation system among health workers. (Table 6) 
Test of Hypothesis: This section examines the effect of motivation system on staff performance of public health sector. The equation of best fit was selected based on the value of R-adjusted, F-ratio and the number of parameters. Table 7 shows the regression analysis solution. From the table, motivational index has a positive and significant impact on the performance of the staff. The coefficient (0.305) suggests that a $10 \%$ increase in the motivational index of workers would increase staff performance by $3.05 \%$. This indicates that efforts geared towards increasing the performance of the staff should be directed towards increasing their motivational index.

Furthermore, the age of the respondents has a positive impact on their performance. It is also significant at $1 \%$ level. The coefficient value of 0.157 indicates that the higher the age of the staff, the higher their performance. Year of experience has negative effect $(-0.022)$ on staff performance which exert insignificant effect. Although this is contrary to the theoretical a-priori expectation, since it is expected that staff performance should increase possibly due to the fact that they have spent more years on the job. But sometimes at this level, the staff may take time off that was not scheduled or take more leave than necessary which may affects the smooth running of the hospital and can seriously compromised the quality of care which patients receive.

In addition, management-staff relationships have a positive effect on the staff performance. This is in line with the theoretical a-priori expectation since it is expected that the stronger the cordial relationship between the management and staff, the more motivated the staff would be, which should in turn increase performance. The value 0.156 suggests that a $1 \%$ increase in the management-staff relationship would increase the staff performance by 0.156 . (Table 7). The negative value $(-0.081)$ of gender, suggest that the more male staff the hospital has, the lower the performance. This indicates that female staff has higher performance than male. Thus, in order to have a higher performance in this sector, employment of more female staff is suggested. Also, nature of job has a negative $(-0.003)$ effect on workers performance, though the value is not statistically significant. It can be deduced from the foregoing that workers who do menial jobs and dirty jobs may not be motivated to perform (Table 7).

Table 4: Perception of workload and remuneration

\begin{tabular}{|c|c|c|c|c|c|c|}
\hline Variables & $\begin{array}{l}\text { Nurses } \\
\text { midwives } \\
\mathrm{n}=33\end{array}$ & $\begin{array}{l}\text { Laboratory } \\
\text { scientists } \\
n=4\end{array}$ & $\begin{array}{l}\text { Pharmacists } \\
n=5\end{array}$ & $\begin{array}{l}\text { Doctors } \\
n=6\end{array}$ & $\begin{array}{l}\text { Other } \\
\text { supporting } \\
\text { staff } \\
n=57\end{array}$ & $\begin{array}{l}\text { Total } \\
n=105\end{array}$ \\
\hline $\begin{array}{l}\text { Perception of } \\
\text { workload } \\
\text { Happy and } \\
\text { satisfied } \\
\text { Overworked } \\
\text { Under-utilized } \\
\text { No response }\end{array}$ & $\begin{array}{l}20 \\
13 \\
0 \\
0\end{array}$ & $\begin{array}{l}3 \\
1 \\
0 \\
0\end{array}$ & $\begin{array}{l}5 \\
0 \\
0 \\
0\end{array}$ & $\begin{array}{l}4 \\
2 \\
0 \\
0\end{array}$ & $\begin{array}{l}30 \\
20 \\
0 \\
7\end{array}$ & $\begin{array}{l}62(59.05 \%) \\
36(34.3 \%) \\
0 \\
7(6.65 \%)\end{array}$ \\
\hline $\begin{array}{l}\text { Remunerated } \\
\text { as and when } \\
\text { due } \\
\text { Yes } \\
\text { No }\end{array}$ & $\begin{array}{l}18 \\
15\end{array}$ & $\begin{array}{l}2 \\
2\end{array}$ & $\begin{array}{l}5 \\
0\end{array}$ & $\begin{array}{l}3 \\
3\end{array}$ & $\begin{array}{l}40 \\
17\end{array}$ & $\begin{array}{l}68(64.76 \%) \\
37(35.24 \%)\end{array}$ \\
\hline $\begin{array}{l}\text { Satisfaction } \\
\text { with present } \\
\text { remuneration } \\
\text { Yes } \\
\text { No } \\
\text { Don't know }\end{array}$ & $\begin{array}{l}10 \\
22 \\
1\end{array}$ & $\begin{array}{l}1 \\
3 \\
0\end{array}$ & $\begin{array}{l}4 \\
1 \\
0\end{array}$ & $\begin{array}{l}2 \\
4 \\
0\end{array}$ & $\begin{array}{l}30 \\
20 \\
7\end{array}$ & $\begin{array}{l}47(44.76 \%) \\
50(47.62 \%) \\
8(7.62 \%)\end{array}$ \\
\hline
\end{tabular}

Source: Field survey, 2010 
Am. J. Sci. Ind. Res., 2011, 2(2): 216-223

Table 5: Managerial characteristics

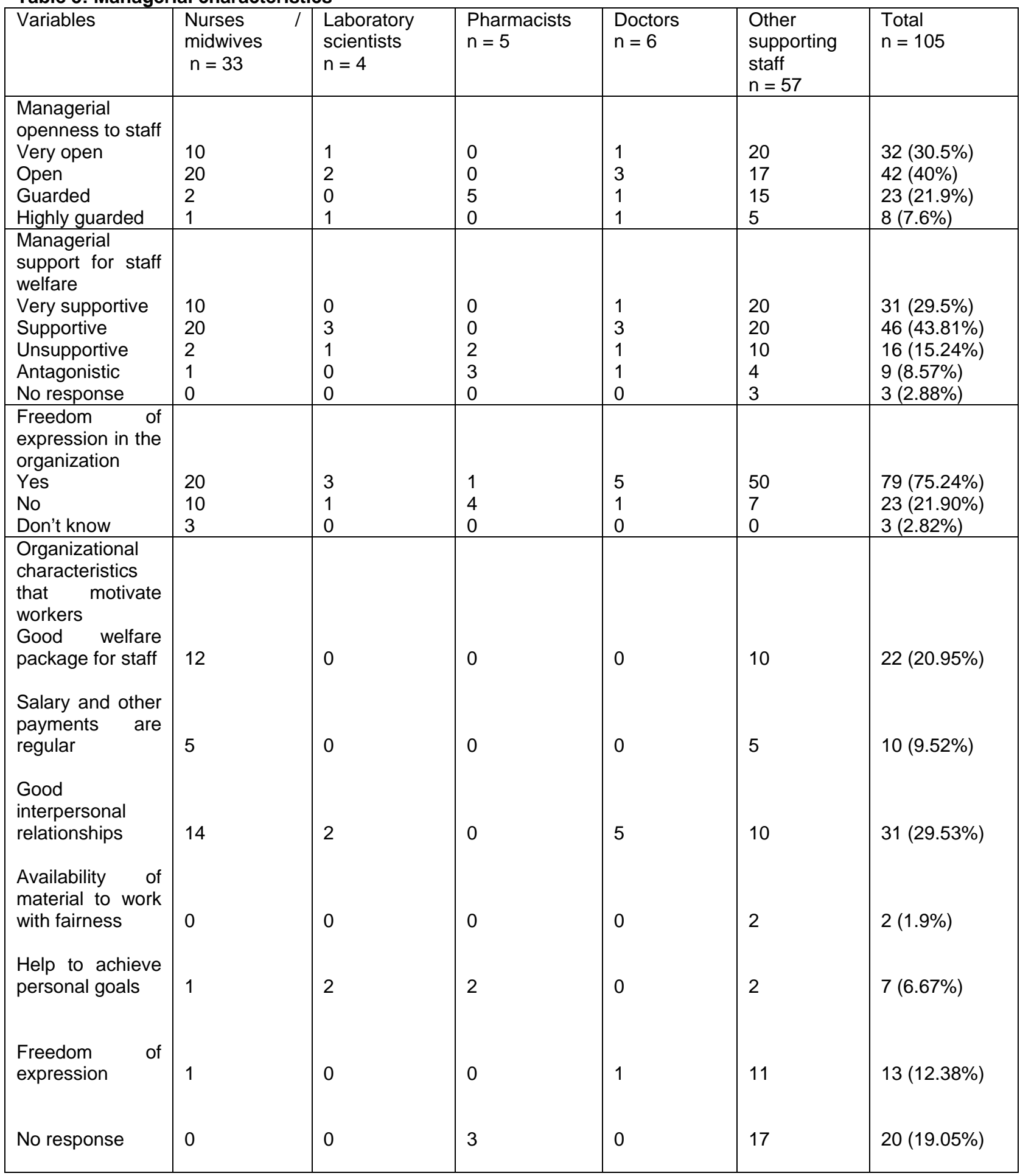

Source: Field survey, 2010 
Am. J. Sci. Ind. Res., 2011, 2(2): 216-223

Table 6: Factors militating against compensation system and solutions

\begin{tabular}{|l|l|l|l|l|l|l|}
\hline Factors/solutions & $\begin{array}{l}\text { Strongly } \\
\text { Agreed }\end{array}$ & Agreed & Undecided & Disagreed & $\begin{array}{l}\text { Strongly } \\
\text { disagreed }\end{array}$ & Total \\
\hline PI & $75(71.4 \%)$ & $26(24.8 \%)$ & - & - & $4(3.8 \%)$ & $105(100 \%)$ \\
\hline ABS & $75(71.4 \%)$ & $28(26.7 \%)$ & - & - & $2(1.9 \%)$ & $105(100 \%)$ \\
\hline LG & $65(61.9 \%)$ & $40(38.1 \%)$ & - & - & - & $105(100 \%)$ \\
\hline IHR & $78(74.3 \%)$ & $27(25.7 \%)$ & - & - & - & $105(100 \%)$ \\
\hline RCMC & $78(74.3 \%)$ & $27(25.7 \%)$ & - & - & - & $105(100 \%)$ \\
\hline SPS & $26(24.8 \%)$ & $10(9.5 \%)$ & - & $14(13.3 \%)$ & $55(52.4 \%)$ & $105(100 \%)$ \\
\hline PGB & $60(57.1 \%)$ & $35(33.3 \%)$ & - & - & $10(9.5 \%)$ & $105(100 \%)$ \\
\hline GG & $79(75.2 \%)$ & $26(24.8 \%)$ & - & - & - & $105(100 \%)$ \\
\hline HR & $66(62.9 \%)$ & $38(36.2 \%)$ & - & - & $1(1.0 \%)$ & $105(100 \%)$ \\
\hline
\end{tabular}

Source: Field survey, 2010

Table 7: Results of Tobit Regression Analysis

\begin{tabular}{|l|l|l|}
\hline Variables & Coefficients & t-ratios \\
\hline Constant & 1.115 & $6.4 \mathrm{G}$ \\
\hline Motivational Index & 0.305 & 4.546 \\
\hline Age & 0.054 & 1.050 \\
\hline Gender & -0.081 & -1.224 \\
\hline Nature of job & -0.003 & -0.366 \\
\hline $\begin{array}{l}\text { Management-staff } \\
\text { relationships }\end{array}$ & 0.016 & 0.260 \\
\hline Experience & -0.022 & -1.152 \\
\hline
\end{tabular}

Source: Data analysis, 2010

The calculated F-ratio for the Tobit regression model is 4.38 and it is significant at $1 \%$, which shows an overall goodness of fit of the model. Since the whole model is fit, we accept the alternative hypothesis $[\mathrm{H} 1]$. We thus conclude that the motivational systems of University of llorin teaching hospital have significance influences on the performance of the health care workers.

\section{DISCUSSION}

Findings from this study revealed that $59.05 \%$ of the respondents were happy with their workload, and $64.76 \%$ were paid as and when due; however, about half $(47.62 \%)$ of the respondents felt underpaid for the work they did. It was unexpected to find such a high proportion of health workers feeling satisfied with their salaries in view of the fact that a major cause of health workers migration in Africa is better remuneration (Stilwell, et al., 2004). The study also showed that nonmonetary factors such as interpersonal relationships, quality of supervision, availability of tools and equipment to work with, as well as managerial fairness, support for staff welfare and training, appear to play a significant role in affecting health workers satisfaction with their work. This agrees with findings from studies done in Ghana, Kenya and Mali (Agyepong, et al., 2004;
Dieleman, et al., 2006; Mbindyo, et al., 2009; and Stilwel, et al., 2004). However, the media and the information sector tend to portray monetary benefits as being a major factor in worker motivation and staff retention, at least in Nigeria.

Also, the effect of compensation system on performance was obtained using the Tobit regression analysis. From findings, motivational indexes, age and management-staff relationship have positive values of coefficients: $0.305,0.054$ and 0.016 respectively while the gender, nature of job and years of experience have negative values of $-0.081,-0.003$ and -0.022 respectively. The F-ratio calculated was 4.38 and it was significant at $1 \%$ which shows that the model is fit. The coefficient of determination $\mathrm{R}^{2}$ is 0.212 indicating that out of the total variation in the staff performance, only $21.2 \%$ was affected by the independent variables [motivational index, age, gender, nature of job, management-staff relationship and experience]

\section{CONCLUSION}

It is clear factors influencing health workers motivation are interlinked, complex, and operate at different levels. While most of those at a national level currently negatively influence health workers motivation in University of Ilorin teaching hospital, kwara state, it is noteworthy that some improvement in motivation can be attributed to how well a hospital's management organizes and runs the hospital. Workers' monetary considerations cannot be gainsaid; however, implementing nonmonetary factors like quality of supervisions, availability of tools and materials to work with, staff welfare and career development also appears to be important in creating satisfaction with job environment. 


\section{REFERENCES}

Agyepong, I (1999): "Reforming health service delivery at district level in Ghana: The perspective of a district medical officer". Health Policy Plan vol 14, pp 59-69.

Bennett, S and Lynne, M. F (1999): "Public Sector Health Worker Motivation and Health Sector Reform: A conceptual framework". Major Applied Research 5, Technical paper Bethesda, MD: Partnership for health reform project, Abt Associates Inc.

Dieleman, M; Cuong, P; Anh, L and Martineau, T. (2003): "Identifying factors for job motivation of rural health workers in North Viet Nam". Human Resources for Health, vol 1, No. 10, pp 1-10

Dieleman, M; Toonen, J; Toure, H and Martineau, T (2006): "The match between motivation and performance management of health sector workers in Mali". Human Resour Health, vol 4, no 2, pp 23-29.

Dolea, C and Adams, O (2005): "Motivation of health care workers: review of theories and empirical evidence". Cahiers de Sociologie et Demographie Medicale, vol 45, pp 135-161.

Franco, L. M; Bennett, S and Kanfer, R (2002): "Health sector reform and public sector health worker motivation, a conceptual framework". Social Sci Med, vol 54, pp 1255-66

Franco, L. M; Bennett, S; Kanfer, R and Stubblebibe, P. (2004): "Determinants and consequences of health worker motivation in hospitals in Jordan and Georgia". Social Science Med, vol 58, pp 343-55.

Gilson, L; Alilio, M and Heggehougen, K. (1994): "Community satisfaction with primary health careservices: An evaluation undertaken in the Morogoro region of Tanzania". Social Sci. Med, vol39, pp767-80.

Grimshaw, J; Thomas, R, MacLennan, G; Fraser, C; Ramsay, C; Vale, L; Whitty, P; Eccles, M; Matowe, L and Shirran, $L$ (2004): "Effectiveness and efficiency of guideline dissemination and implementation strategies". Health Technology Assessment, vol 8, p 6.

Kyaddondo, D and Whyte, S. R. (2003): "Working in a Decentralized System: A threat to HealthWorkers' Respect and Survival in Uganda". International Journal of Health Planning and Management, vol 18, pp 329-342.

Lindelow, M and Serneels, P (2006): "The performance of health workers in Ethiopia: Results fromqualitative research". Social science and medicine, vol 62, pp 2225-35.
Manongi, R; Marchant, T and Bygbjerg, I. C. (2006): "Improving motivation among primary healthcare workers in Tanzania: a health worker perspective". Human Resources for Health, vol 4, pp 4-6

Manzi, F; Kida, T; Mbuyita, S; Palmer, N and Gilson, L (2004): Health Economics and FinancingProgramme, London School of Hygiene and Tropical Medicine. Johannesburg: Center for Health Policy. "Exploring the influence of workplace trust over health worker performance:preliminary national overview report Tanzania".

Marjolein, D; Pham, V. C; Le, V. A and Tim, M (2003): "Identifying factors for job motivation of rural health workers in North Viet Nam". Human Resour, Vol 1, pp 1-10

Mbindyo, P. M; Blaauw, D; Gilson, L and English, M (2009): "Developing a tool to measure healthworker motivation in district hospitals in Kenya". Human resources for health, vol 7, pp 40-46

Rowe, A. K; de Savigny, D; Lanata, C. F and Victoria, C. G (2005): "How can we achieve and maintain high quality performance of health workers in low resource setting?" The Lancet, vol 366, pp 1026-35

Shaw, B; Cheater, F; Baker, R; Gillies, C; Hearnshaw, H; Flottorp, S and Robertson, N (2005): "Tailored interventions to overcome identified barriers to change: effects on professional practice and health care outcomes". Cochrane Database of Systematic Reviews, p. CD14005470

Stilwell, B (2004): "Managing brain drain and brain waste of health workers in Nigeria". Bull World Health Organ, vol 82, pp 595-600

Stilwel, B; Diallo, K; Zurn, P; Vujicic, M; Adams, O and Dal Poz, M (2004): "Migration of health care workers from developing countries: Strategic approaches to its management". Bull World Health Organ, vol 82, pp 600-607

Wallin, L; Ewald, U; Wikblad, K; Scott-Findlay, $\mathrm{S}$ and Arnetz, B. B (2006): "Understanding workcontextual factors: a short-cut to evidence-based practice". Worldviews on evidence-based nursing, vol 3, pp 153164

Woodward, C (200): Issues in Health service delivery. Geneva: World Health Organization; "Strategies for assisting health workers to modify and improve skills: Developing quality health care- a process of change".

World Health Organization (1993): "Training manual on management of human resources for health". Section 1, part A. Geneva 